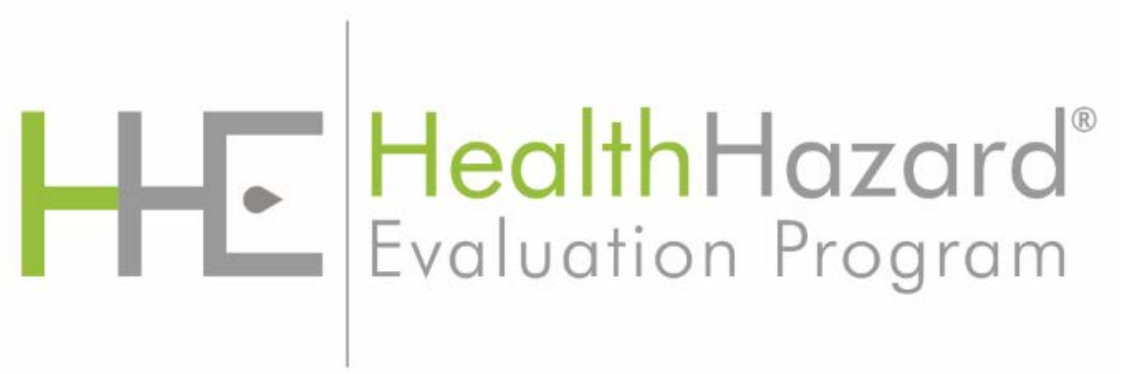

\title{
Evaluation of Lead and Copper Exposure at an Indoor Shooting Range
}

HHE Report No. 2018-0124-3351

May 2019

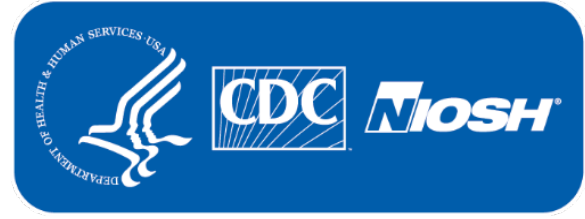




\section{Authors: $\quad$ Michael P. Grant, ScD}

\section{Laura Reynolds, MPH, BSN, RN}

\section{Mark M. Methner, PhD, CIH}

Analytical Support: Maxxam

Desktop Publisher: Jennifer Tyrawski

Editor: Cheryl Hamilton

Industrial Hygiene Field Assistance: Donnie Booher

Logistics: Donnie Booher, Kevin Moore

Medical Field Assistance: John Gibbins

Keywords: North American Industry Classification System (NAICS) 928110 (National Security); California, Exposure, Lead, Copper, Firing Range, Ventilation

\section{Disclaimer}

The Health Hazard Evaluation Program investigates possible health hazards in the workplace under the authority of the Occupational Safety and Health Act of 1970 [29 USC 669a(6)]. The Health Hazard Evaluation Program also provides, upon request, technical assistance to federal, state, and local agencies to investigate occupational health hazards and to prevent occupational disease or injury. Regulations guiding the Program can be found in Title 42, Code of Federal Regulations, Part 85; Requests for Health Hazard Evaluations [42 CFR Part 85].

\section{Availability of Report}

Copies of this report have been sent to the employer, employees, and union at the plant. The state and local health departments and the Occupational Safety and Health Administration Regional Office have also received a copy. This report is not copyrighted and may be freely reproduced.

\section{Recommended Citation}

NIOSH [2019]. Evaluation of lead and copper exposure at an indoor shooting range. By Grant MP, Reynolds L, Methner MM. Cincinnati, OH: U.S. Department of Health and Human Services, Centers for Disease Control and Prevention, National Institute for Occupational Safety and Health, Health Hazard Evaluation Report 2018-0124-3351, https://www.cdc.gov/niosh/hhe/reports/pdfs/2018-0124-3351.pdf. 


\section{Main Report}

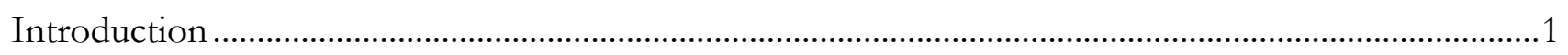

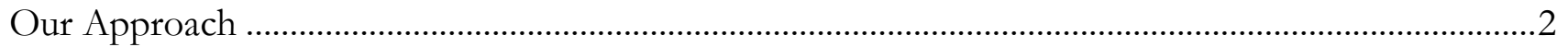

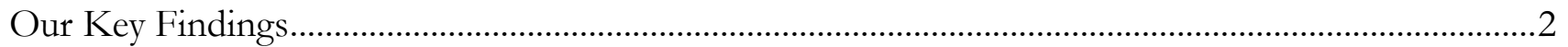

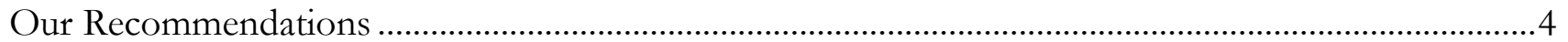

\section{Supporting Technical Information}

Section A: Workplace Information.......................................................................................... A-1

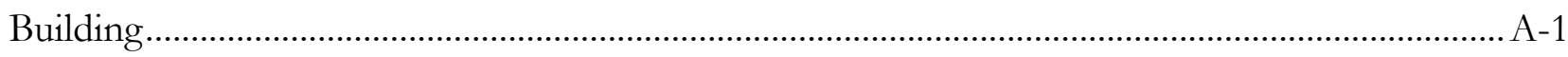

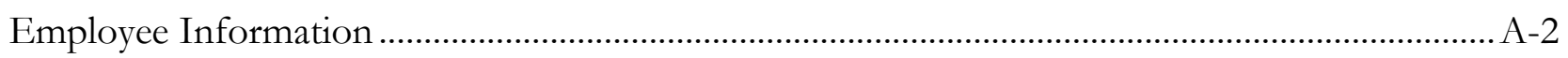

Process Description ............................................................................................... A-2

Section B: Methods, Results, and Discussion ……………………………………………….... B-1

Methods: Observations of Work Processes, Practices, and Conditions ........................................... B-1

Results: Observations of Work Processes, Practices, and Conditions ........................................... B-1

Methods: Exposure Assessment …………………………………………………………..... B-3

Results: Exposure Assessment ...................................................................................... B-4

Methods: Ventilation Assessment......................................................................................... B-5

Results: Ventilation Assessment............................................................................................. B-5

Methods: Employee Health Assessment …………………………………………………... B-6

Results: Employee Health Assessment ........................................................................................ B-6

Methods: Standard Operating Procedures and OSHA Log Review............................................. B-7

Results: Standard Operating Procedures and OSHA Log Review................................................. B-7

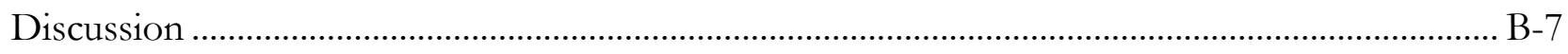

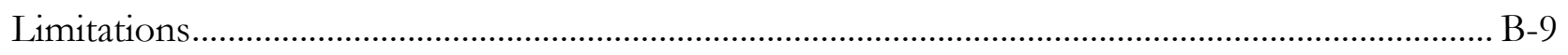

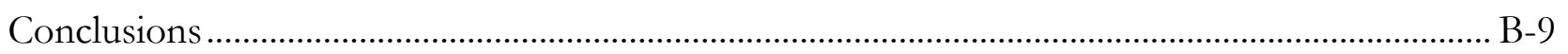

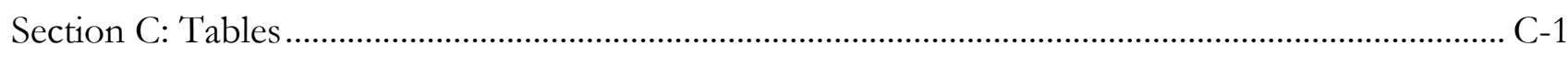

Section D: Occupational Exposure Limits .................................................................................

Copper Particulate (as Fume or Dust/Mist) …………………………………………….... D-2

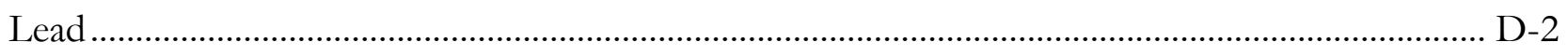

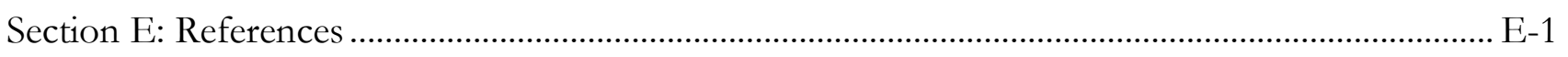


This page left intentionally blank 


\section{Introduction}

\section{Request}

Management from a Department of Defense (DoD) indoor shooting range facility requested a health hazard evaluation concerning employee exposure to lead and copper during cleaning activities.

\section{Workplace}

The facility contained three ranges. Weapons (either rifle or pistol) fired inside of Ranges $\mathrm{A}$ and $\mathrm{C}$ used lead-based ammunition, while those fired inside Range B used frangible copper-based ammunition only. Employees were responsible for daily and weekly cleaning of the ranges in addition to maintenance activities, such as replacing exhaust fan filters and emptying buckets that collect bullets behind the bullet traps.

Daily cleaning of the ranges included the following:

- Pushing a dry, long-handled floor mop to move debris from the firing line toward the target line.

- Sprinkling an ignition-suppressing compound over the debris to reduce the explosion potential of unburnt propellant.

- Removing the debris with a High Efficiency Particulate Air filtered vacuum.

Weekly cleaning included all of the daily cleaning activities plus the following:

- Dry-mopping debris from all bullet trap ramps.

- Using compressed air and a leaf blower to clean particulates deposited between the firing line and the target line/bullet trap ramp in Range B only.

Additional activities included these tasks:

- Exhaust fan prefilters were replaced when the static air pressure readings across the filter exceed a specific threshold value.

- Buckets used to collect spent bullets were emptied as needed—the facility was still determining an optimal change out schedule.

During our first visit, nine employees worked at the facility; during our second visit, seven employees were working. The employees generally worked one 8-hour work shift per day, Monday through Friday. Employees performed their daily and weekly cleaning activities on Day one of air sampling. On Day two of air sampling, workers replaced prefilters and emptied bullet collection buckets behind Range C. On the day they changed prefilters and emptied bullet collection buckets, employees ended their day after the maintenance tasks were complete. Prefilters were changed about every three months.

To learn more about the workplace, go to Section A in the Supporting Technical Information 


\section{Our Approach}

We visited the facility twice in August 2018. We completed the following activities during our evaluation:

- Toured the range facility.

- Reviewed personal protective equipment storage and maintenance practices.

- Reviewed standard operating procedures for cleaning and maintenance activities.

- Reviewed medical and training records.

- Held confidential interviews with employees about their work and health.

- Provided educational materials about take-home lead.

- Observed work processes and work practices.

- Examined the ventilation system.

- Collected air and surface wipe samples for lead and copper.

- Collected colorimetric wipe samples for lead.

- Assisted with the ventilation system performance evaluation.

To learn more about our methods, go to Section B in the Supporting Technical Information

\section{Our Key Findings}

\section{Employees had elevated blood lead levels}

- Two of nine employees had blood lead levels that were above 5 micrograms per deciliter on their most recent blood lead test, a level that the National Institute for Occupational Safety and Health (NIOSH) considers elevated. The range of blood lead levels was $<3.0$ (nondetectable) through 6.5 micrograms per deciliter.

- None of the employees had blood lead levels from their most recent tests that were above the DoD limit of 30 micrograms per deciliter or the Occupational Safety and Health Administration (OSHA) limit of 60 micrograms per deciliter. A blood lead level at or above the DoD limit of 30 micrograms per deciliter requires temporary removal from the workplace.

- Current evidence regarding health effects of lead in adults is summarized in Table D1. 


\section{Employees' airborne exposures to lead during some tasks were above occupational exposure limits}

- Employees' personal air exposures to lead ranged from 57 through 6,500 micrograms per cubic meter of air while changing prefilters and emptying bullet collection buckets in Range $\mathrm{C}$. Assuming zero exposure for the remainder of the day, the calculated 8-hour time-weighted average exposures to lead ranged from 22 through 2,400 micrograms per cubic meter of air. Four out of five employee exposures exceeded the current OSHA permissible exposure limit and the NIOSH recommended exposure limit for lead of 50 micrograms per cubic meter of air.

- Employees' full-shift personal air exposures to lead ranged from 0.14 through 36 micrograms per cubic meter of air while performing daily and weekly cleaning. These exposures are below the current OSHA permissible exposure limit and the NIOSH recommended exposure limit for lead of 50 micrograms per cubic meter of air. One employee's exposure was higher than the OSHA action level of 30 micrograms per cubic meter of air.

- Employees wore powered air purifying respirators while changing prefilters and emptying bullet collection buckets, which were appropriate for the measured airborne lead concentrations when using OSHA assigned protection factors. These respirators were not appropriate for the measured concentrations when using NIOSH assigned protection factors.

- Range A's ventilation system was operating in accordance with NIOSH guidelines. Some of the air velocities measured in Range B were lower than NIOSH guidelines; we identified one partially closed air supply register that reduced air velocity in one area of Range B. We were unable to evaluate Range $\mathrm{C}$ during our visit because it was occupied with personnel firing weapons each day.

\section{Work practices could contribute to lead exposure}

- Some employees did not don (put on) and doff (take off) personal protective equipment according to the facility's standard operating procedures. Not all employees were wearing double gloves even though it was required by the standard operating procedures. There were employees who tore their Tyvek ${ }^{\circledR}$ suits or gloves while changing prefilters or emptying the buckets. They did not stop and replace their torn gloves or suits to prevent further contamination.

- Some employees reported not washing their hands prior to eating.

- Annual lead training did not include information about take-home lead exposure.

- Some employees did not have dedicated work clothes and shoes. Some reported not changing into clean clothes and/or showering after a work shift. However, laundry, locker, and showering facilities were available at the worksite.

- Colorimetric wipes did not reveal lead on the hands and boots of employees, but we did find lead and copper on surfaces within the facility. Proper hand hygiene and wearing shoe covers were likely effective in reducing potential exposure. 
- Sinks in the entry rooms of the ranges had manually operated faucet handles that could contribute to lead exposure after handwashing.

\section{Standard operating procedures and the lead control plan were in compliance with OSHA standards}

- Employees were monitored and tested for lead exposure and received annual training on the health hazards of lead.

- Standard operating procedures were easily accessible and included detailed information regarding safety protocols and personal protective equipment use.

To learn more about our results, go to Section B in the Supporting Technical Information

\section{Our Recommendations}

The Occupational Safety and Health Act requires employers to provide a safe workplace.

Benefits of Improving Workplace Health and Safety:

The recommendations below are based on the findings of our evaluation. For each recommendation, we list a series of actions you can take to address the issue at your workplace. The actions at the beginning of each list are preferable to the ones listed later. The list order is based on a well-accepted approach called the "hierarchy of controls." The hierarchy of controls groups actions by their likely effectiveness in reducing or removing hazards. In most cases, the preferred approach is to eliminate hazardous materials or processes and install engineering controls to reduce exposure or shield employees. Until such controls are in place, or if they are not effective or practical, administrative measures and personal protective equipment might be needed. Read more about the hierarchy of controls at https://www.cdc.gov/niosh/topics/hierarchy/.

We encourage the company to use a health and safety committee to discuss our recommendations and develop an action plan. Both employee representatives and management representatives should be included on the committee. Helpful guidance can be found in "Recommended Practices for Safety and Health Programs" at https://www.osha.gov/shpguidelines/index.html. 


\section{Recommendation 1: Improve compliance with standard operating procedures}

Why? Compliance with standard operating procedures ensures that work processes are performed in a consistent manner. Consistency is important to make certain that all employees are protected while working. Improved training can increase compliance and comfort with standard operating procedures.

There was some confusion around proper personal protective equipment donning and doffing procedures. Some employees needed guidance to put on the Tyvek suits and respirators. Not all employees were wearing required equipment, or changing equipment when it became damaged.

The standard operating procedures in place at this facility were designed to protect employees and should effectively minimize unnecessary exposures to lead and copper while working on the ranges. More frequent training and hands-on practice with the equipment and processes will improve compliance with the established standard operating procedures.

How? At your workplace, we recommend these specific actions:

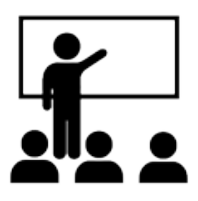

\section{Provide periodic refresher training related to the standard operating} procedures for each task.

- More frequent training will help improve compliance with procedures, especially if the procedures are changed.

- Each time you change any procedure, review those changes with employees. Consider holding periodic, hands-on, "dry run" training.

- Consider setting aside time prior to the next bucket or filter change to provide hands-on training to employees as they don and doff their personal protective equipment. Guiding employees through the process will improve future compliance with standard operating procedures.

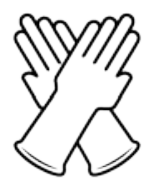

\section{Review whether personal protective equipment sizes are appropriate for employees.}

- Ensure appropriate sizes for Tyvek suits and nitrile gloves are available. This will reduce the potential for suit and glove tearing during maintenance activities. If suits appear to fit the employee but consistently tear during use, the employee may require a larger size to accommodate body movement during work tasks.

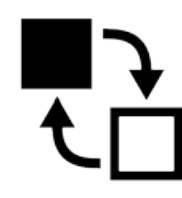

\section{Encourage employees to stop work and replace suits and gloves if they} become torn.

- Create a standard operating procedure that instructs employees on what to do in the event of personal protective equipment failure. 
Recommendation 2: Ensure annual training includes materials on take-home lead exposure and the importance of lead hygiene practices

Why? Lead dust can be carried out of the workplace on clothes, shoes, and skin. Employees should take precautions to prevent contaminating their vehicles and homes with lead. Without removing lead dust prior to entering vehicles and homes, employees may expose other adults and children to takehome lead, which can cause adverse health effects.

We observed that annual training materials did not include information about take-home lead. We also observed that not all employees washed their hands when leaving the range. We saw employees who did not change out of their street clothes and into work clothes or boots when arriving to and departing from the facility. Only two employees reported showering at work before leaving for the day.

How? At your workplace, we recommend these specific actions:

Encourage employees to use the onsite laundry facilities to wash lead dust from work clothes.

- Wash and store work clothes in lockers at the facility.

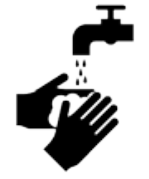

Wash hands when leaving the range and shower before leaving the facility.

Consider replacing manually operated faucets in the sinks in the entry rooms with hands-free faucets to decrease the likelihood of contaminating the handles with lead.

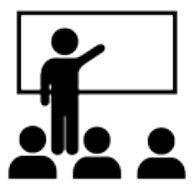

Include take-home lead exposure information in annual training materials.

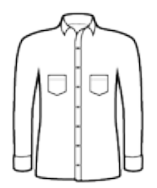

Consider providing work clothes that employees can launder and store at the workplace. 


\section{Encourage employees to change into work clothes before their shift at the facility.}

- Put on work clothes and boots at the beginning of each shift.

- Change back into street clothes and shoes before leaving the facility each day.

- Leave work clothes and boots at the facility.

\section{Recommendation 3: Address other health and safety issues identified during our evaluation}

Why? A workplace can have multiple health hazards that cause worker illness or injury. Similar to the ones identified above, these hazards can potentially cause serious health symptoms, lower morale and quality of life for your employees, and costs to your organization. We saw the following potential issues at your workplace:

- Employees wore respirators not appropriate when using NIOSH selection criteria.

- Ventilation system evaluations do not follow NIOSH guidelines.

- Workers used only dry-cleaning methods.

- Surface contamination was detected on chairs in the maintenance area.

- OSHA 300 Logs were not used.

Although they were not the focus of our evaluation, these hazards could cause harm to your workers' health and safety and should be addressed.

How? At your workplace, we recommend these specific actions:

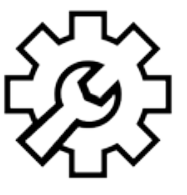

Consider changes to maintenance tasks involving filters and buckets.

- Investigate the possibility of using a spray bottle with water to lightly mist the filters and bullet collection buckets prior to removal. This treatment may reduce the amount of lead dust released to the air during such activities. Also, change filters and empty buckets on different days - this will likely reduce potential lead exposures and better protect employees.

- Use respiratory protection following NIOSH guidance - employees performing these tasks should wear a pressure-demand supplied-air respirator with a half-mask or a full facepiece. NIOSH guidance is more protective. 


\section{Consult with a ventilation engineer to evaluate the feasibility of local exhaust ventilation while changing filters and emptying buckets.}

- Installing engineering controls is the preferred method of reducing exposures, especially because the lead exposure levels were very high while changing filters and emptying the buckets.

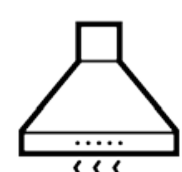

II

\section{Adjust how ventilation system performance is assessed.}

- Assure that the average air velocity of each firing line is greater than 50 feet per minute. The ideal average air velocity is 75 feet per minute.

- Apply minimal adjustments to current practices to bring ventilation assessments in line with NIOSH guidelines.

- Measure the average air velocity along the firing line (across the range rather than down range), not the firing lane. Currently, air velocities are averaged along the firing lane.

\section{Use wet-cleaning methods after the range floor has been vacuumed to help reduce contamination.}

- Adding a walk-behind wet floor scrubber to clean the range floor at the end of each week would provide a periodic "deep clean" of the range floors.

- Using a de-leading solution in the scrubber water will increase lead removal effectiveness.

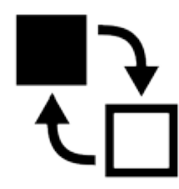

\section{Consider using different chairs when emptying the buckets behind the} bullet trap.

- Chairs should be made of less porous material that is easier to clean after being contaminated with lead dust.

\section{Keep OSHA Logs of Work-Related Injuries and IIInesses.}

- Maintain these logs even if there are no recordable injuries and illnesses for the year.

- Keep the logs in accordance with 29 CFR 1904.31 Recording and Reporting Occupational Injuries and Illness.

- Include OSHA Form 300 (Log of Work-Related Injuries and Illnesses), OSHA Form 300A (Summary of Work-Related Injuries and Illnesses), and OSHA Form 301 (Injury and Illness Incident Reports).

- Include contractors on the logs for the range facility because these employees are supervised by your organization on a day to day basis. 


\section{Supporting Technical Information}

Evaluation of Lead and Copper Exposure at an Indoor Shooting Range

HHE Report No. 2018-0124-3351

May 2019 


\section{Section A: Workplace Information}

\section{Building}

- The indoor shooting range facility (Figure A1) opened in May 2017 and consisted of three ranges $(\mathrm{A}-\mathrm{C})$ in one building. Adjacent to each range was a room that had a sink, hearing protection storage area, and a control room. The control room had workstations with computers and video screens to monitor the shooters and targets. A separate building adjacent to the range facility housed the employees' office space and classrooms.

- Range A had 30 firing lanes but no firing stalls. There were firing lines marked on the floor at $3,7,10,15$, and 25 yards away from the target line. Range B was a six lane reactive steel target range equipped with programmable pop up targets. Each lane had one firing line with multiple firing positions, and the lane was separated by a wall running from the firing line toward the bullet trap. Shooters/instructors in Range B could program the target system to present various target configurations. Range $\mathrm{C}$ was similar but larger in square footage than Range A (open floor plan) and had 13 lanes. There were firing lines at 3, 7, 10, 25, and 50 yards. Range $C$ was able to accommodate vehicles, barricades, and other equipment that allows shooters to engage in a variety of tactical drills.

- A large maintenance shop was located behind Range B. This room also had employee lockers, showers, laundry facilities, and a computer workstation where the ventilation system could be monitored.

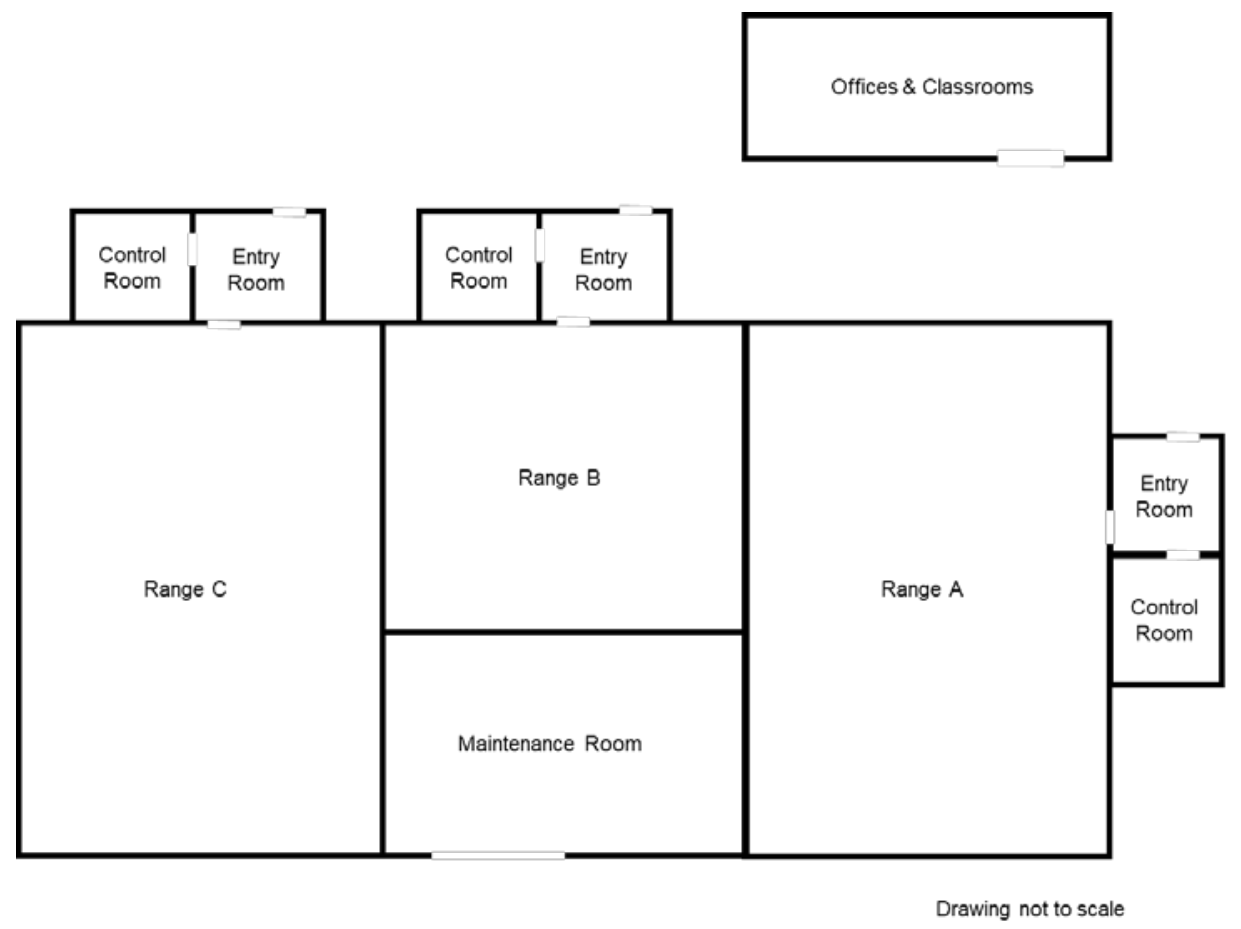

Figure A1. Layout of the indoor shooting range facility and separate office and classroom building nearby. Figure by NIOSH. 


\section{Employee Information}

- Three employees and six contractors worked at the range at the time of our initial visit. None were unionized. On our second visit, there were two employees and five contractors working at the range.

- The employees served as range safety officers, while the contractors primarily performed range maintenance and cleaning. No employee or contractor performed range instructor duty or fired weapons during our visit.

- The work shift was 8 hours (hrs) per day, Monday through Friday, depending on the amount and scope of work scheduled for that day. On the second day of sampling, the employees' full shift consisted of working about 2-3 hrs while they were changing exhaust prefilters and emptying buckets behind the bullet trap in Range C.

\section{Process Description}

The work performed on the ranges changed daily. Generally, Monday through Thursday, there was an "open shoot" in the morning where individuals could use a range. After lunch, the ranges could be reserved for group shooting and training. When the ranges were in use, some employees served as range safety officers, while other employees performed administrative or cleaning and maintenance tasks in ranges that were not in use. On Fridays, there was sometimes an "open shoot" or reserved shoot in the morning, but the remainder of the day was dedicated to weekly cleaning and range maintenance activities.

Daily cleaning of the ranges included these tasks:

- Pushing a dry, long-handled floor mop to move debris from the firing line toward the target line.

- Sprinkling an ignition-suppressing compound over the debris to reduce the explosion potential of unburnt propellant.

- Removing the debris with a High Efficiency Particulate Air (HEPA) vacuum.

Weekly cleaning included all of the daily cleaning activities plus the following:

- Dry-mopping debris from all bullet trap ramps.

- Using compressed air and a leaf blower to clean particulates deposited between the firing line and the target line/bullet trap ramp in Range B only.

Additional periodic maintenance activities:

- Exhaust fan prefilters were replaced when static air pressure readings across the filter exceed a specific value.

Buckets used to collect spent bullets were emptied as needed. They were working on establishing a schedule based on range usage. 


\section{Section B: Methods, Results, and Discussion}

Our objectives included the following:

- Assess employee exposure to lead and copper.

- Evaluate the ventilation system performance.

- Determine the prevalence of elevated blood lead levels (BLL) by reviewing employees' BLL results.

- Review standard operating procedures (SOPs) and training records.

We made two visits to the facility. On the initial visit, we reviewed SOPs, employee training records, and employee BLL reports. We also conducted confidential employee interviews about work practices and health, toured the facility, and observed work practices. During the second visit, we observed work processes and practices while employees completed daily and weekly cleaning on all three ranges. We also observed additional maintenance activities on Range C.

\section{Methods: Observations of Work Processes, Practices, and Conditions}

We evaluated the following in Ranges A-C, the maintenance room, and the adjacent office and classroom building:

- Work processes

- Personal protective equipment (PPE) use

- Workplace conditions

\section{Results: Observations of Work Processes, Practices, and Conditions}

- Employees performed their daily and weekly cleaning activities on Day one of air sampling. On Day two of air sampling, workers replaced prefilters and emptied bullet collection buckets behind Range C. We observed about 35 filters being changed in each of the two exhaust fan units and 69 bullet-collection buckets behind the bullet trap in Range C being emptied during our visit.

- Employees were required to wear eye protection when cleaning on the range. We observed that all employees complied with this requirement.

- Double hearing protection was required in the shooting area when firing events were occurring. Hearing protection was recommended but not required while working in the control room when the range was in use. There were occasions when the door to the range and the door to the control room were opened at the same time resulting in weapon noise entering the control room and adjacent entry vestibule area. Some employees wore hearing protection when in the control room while the range was in use. We observed all employees wearing hearing protection while Range B was cleaned with compressed air and a leaf blower. 
- Employees wore a Tyvek ${ }^{\circledR}$ suit, shoe covers, nitrile gloves, and a disposable hooded powered air purifying respirator (PAPR) equipped with a P100 filter when replacing air filters or emptying bullet-collection buckets. Employees were required to wear two pairs of gloves, but we observed some employees only wearing one pair.

- Tyvek suits, shoe covers, nitrile gloves, and PAPR hoods were discarded after use. PAPR components (e.g., air hose, battery pack) were wiped with lead removal wipes after use. Elastomeric respirators were cleaned with respirator cleaning wipes and stored in bags inside their original box in a cabinet in the maintenance room. Most other PPE was also stored in the maintenance room.

- Employees wore a Tyvek suit with a hood, shoe covers, nitrile gloves, and full-face, tight-fitting, elastomeric air purifying respirator equipped with P100 filters when cleaning the bullet trap ramps. Employees who were not walking on the ramp were only required to wear nitrile gloves and safety glasses.

- Some employees had difficulty donning and doffing PPE. Employees were observed helping each other navigate this process.

- Multiple employees experienced tears in their gloves and Tyvek suits while emptying buckets, but they continued to work.

- After emptying the bullet-containing buckets and changing the air filters, any equipment brought inside this area (e.g., small rolling chairs used while emptying buckets) were wiped with lead removal wipes.

- When pushing debris down range, employees were observed pushing the mop for varying distances, lifting the mop head a few inches off the ground, and gently shaking the head before resuming the push of debris down range.

- Each range had its own HEPA filter vacuum that did not leave the range unless there was an urgent need. While we were there, the vacuum on one range suddenly broke, and a vacuum from an adjacent range was brought in. To reduce the potential for migration of contaminants from one range to another, the replacement vacuum was decontaminated (wiped down with lead removal wipes) prior to returning it.

- Lead removal wipes were used to wipe down many of the surfaces inside the range. We observed employees wiping down various objects, such as table tops, carts, the door handle, the ledge of the window to the control room, the handle of the bullet casing sweeper, and the handles of cleaning instruments (e.g., mop handles). We did not observe employees cleaning the control rooms but were told that they were cleaned approximately once per week.

- Adhesive mats were on the floor just before the exit door from the range into the entry vestibule with the sink and PPE storage. It appeared that these mats were changed at the end of each day.

- Some employees washed their hands before leaving the range building. All employees and visitors were required to wash their hands in the sink outside of the range before exiting the 
building. The only soap at these sinks was lead removal soap. The sink faucets were manually operated.

- Two employees showered at the end of each day.

- All employees had lockers at the facility. Some employees changed into work clothes and boots at the facility.

- Each week, employees replaced the heads on the floor mops they used to dry-sweep debris. Every range had its own set of mops that did not leave the range.

- Most employees left the facility for lunch. Those that stayed ate in the office/classroom building.

- Current lead training did not include information about the possibility of take-home lead.

\section{Methods: Exposure Assessment}

\section{Air Sampling}

We collected personal air samples on seven employees across two days using 37-millimeter diameter, 0.8-micrometer pore size mixed cellulose ester filters and pumps calibrated at a flow rate of 2 liters per minute.

- We analyzed each sample for lead and copper using the NIOSH Method 7303 [NIOSH 2019]. For time-weighted average (TWA) calculations we used the limit of detection divided by the square root of 2 to replace nondetectable values.

- We removed most of the air samplers from employees during their lunch break unless they stayed in the facility and did not request removal.

\section{Surface Wipe Sampling}

We collected surface wipe samples in the range, office, maintenance, and classroom areas. Each sample was collected using a premoistened Ghost Wipe ${ }^{\mathrm{TM}}$ in accordance with NIOSH Method 9100. We used a 100-square-centimeter disposable template to outline the surface area that we sampled. When a template was not feasible (e.g., the handle of the bullet casing sweeper) we estimated 100 square centimeters. We analyzed the wipe samples for lead and copper using NIOSH Method 7303 [NIOSH 2019].

\section{Hand and Shoe Wipe Sampling}

We collected hand and shoe sole wipe samples pre- and postshift for seven employees. We had each employee wipe the palm and back surfaces of each hand with a clean, premoistened Palintest ${ }^{\mathrm{TM}}$ wipe for approximately one minute. We had employees wipe the bottom of one sole with another wipe for approximately one minute. We made sure that employees wiped the bottom of one shoe preshift and the opposite shoe postshift. Hand and shoe wipe samples were evaluated onsite using a Full Disclosure $^{\circledR}$ qualitative colorimetric screening method for lead. 


\section{Results: Exposure Assessment}

\section{Air Sampling}

- On Day one, air samples for lead ranged 0.15-36 micrograms per cubic meter $\left(\mu \mathrm{g} / \mathrm{m}^{3}\right)$. All were below the current OSHA, NIOSH, and American Conference of Governmental Industrial Hygienists $\left(\mathrm{ACGIH}^{\circledR}\right.$ ) occupational exposure limits (OELs) of $50 \mu \mathrm{g} / \mathrm{m}^{3}$ (Table C1). However, one employee's air sample was higher than the OSHA action level (AL) of $30 \mu \mathrm{g} / \mathrm{m}^{3}$. The employees who had higher concentrations on Day one were those workers involved in cleaning off the bullet trap ramp.

- On Day two, air samples for lead ranged 57-6,500 $\mu \mathrm{g} / \mathrm{m}^{3}$ (Table C2). Employees were sampled for their entire shift, which consisted of approximately 2 to 3 hrs of work on that day. The predominant tasks on Day two were changing exhaust prefilters and emptying buckets behind the bullet trap in Range C.

- For comparison with the relevant OELs, we calculated the employees' 8-hr TWA, assuming zero exposure for the hours they were not working. The calculated concentrations are listed in Table C2. Employees' 8-hr TWA exposure to lead ranged 22-2,400 $\mu \mathrm{g} / \mathrm{m}^{3}$. Four of the five employees' 8-hr 'TWA exposures exceeded the OSHA, NIOSH, and ACGIH OELs of $50 \mu \mathrm{g} / \mathrm{m}^{3}$. If employees were to conduct these tasks for a full workday ( 8 hours), exposures would be up to 130 times higher than the OELs.

- We calculated the effective airborne lead concentrations using NIOSH and OSHA assigned protection factors (APF) for the respirators worn by employees (Table C3). The task-based and 8-hr concentrations were divided by either 25 (the NIOSH APF) or 1,000 (the OSHA APF), and the effective lead concentrations were calculated. Employees were above lead OELs if using a respirator with an APF of 25, but they were under all applicable OELs when using a respirator with an APF of 1,000 .

- All air samples collected on both days for total copper dust were lower than the OSHA, NIOSH, and ACGIH OELs of $1,000 \mu \mathrm{g} / \mathrm{m}^{3}$.

\section{Surface Wipe Sampling}

We found copper and lead on most surfaces that we sampled (Table C4) with the exception of the breakroom counter and a classroom desktop. The highest concentrations of lead were found on the Range C cart handle (110 micrograms per 100 square centimeters $\left.\left[\mu \mathrm{g} / 100 \mathrm{~cm}^{2}\right]\right)$ and on the back of a chair $\left(370 \mu \mathrm{g} / 100 \mathrm{~cm}^{2}\right)$ in the maintenance room. The cart was used to hold ammunition inside Range $\mathrm{C}$. The chair in the maintenance room was used while emptying the bullet-collection buckets behind the bullet trap. The chair and cart went through a decontamination process before we took our sample.

We found lead $\left(<10 \mu \mathrm{g} / 100 \mathrm{~cm}^{2}\right)$ and copper $\left(<310 \mu \mathrm{g} / 100 \mathrm{~cm}^{2}\right)$ on surfaces we sampled inside all of the control rooms. Most of lead concentrations we measured in this area were below the analytical method's limit of quantification. We also found lead $\left(<13 \mu \mathrm{g} / 100 \mathrm{~cm}^{2}\right)$ and copper $\left(<39 \mu \mathrm{g} / 100 \mathrm{~cm}^{2}\right)$ on most office and classroom surfaces. Similar to the control rooms, most of the lead concentrations we measured were below the limit of quantification. The highest levels were detected on the keyboard 
wrist rest in the office area $\left(13 \mu \mathrm{g}\right.$ lead $/ 100 \mathrm{~cm}^{2}$ and $39 \mu \mathrm{g}$ copper $\left./ 100 \mathrm{~cm}^{2}\right)$. There are no OELs for surface contamination of either lead or copper.

\section{Hand and Shoe Wipe Sampling}

We did not detect any lead on any of the pre- and postshift hand or shoe wipe samples. Over the course of the shift, employees wore disposable shoe covers when replacing air filters, emptying bulletcollection buckets, or cleaning the bullet trap ramp.

\section{Methods: Ventilation Assessment}

During our visit, we assisted health and safety staff with a ventilation system evaluation. We measured air velocities in Ranges A and B but were unable to assess Range $C$ because it was in use. The week after we left, the health and safety staff conducted an assessment of Range $C$ following the same measurement protocol we used. The information collected by the staff for Range $\mathrm{C}$ is included in this report.

In all ranges, air is supplied by radial diffusers located at the top of the wall behind the firing line. These diffusers were designed to direct air in a uniform manner toward the firing line and downrange past the shooter. We used three electronic micromanometers (Shortridge Instruments, Inc., AirData Multimeter Model ADM-860C) to measure air velocity. We took measurements in each firing lane at heights of 1, 3, and 5 feet above the floor and then computed an average. We repeated this measurement process for each lane until we came to the end of the firing line. We then repeated this measurement process for each firing line until we reached the target line/bullet trap. We then calculated an average air velocity for each firing line.

\section{Results: Ventilation Assessment}

The exhaust component of the ventilation system consisted of six exhaust fan units: three for Range A, one for Range B, and two for Range $C$. The exhaust fan units all drew air from behind the bullet trap through a three-stage filter arrangement before exhausting to the outdoors. The first stage contained Minimum Efficiency Reporting Value (MERV) 8 prefilters. The second stage contained MERV 15 filters. The third stage had HEPA filters.

NIOSH recommends a minimum average air velocity of 50 feet per minute (fpm) at the shooting position (lane) along each firing line. An average of $75 \mathrm{fpm}$ at each lane is ideal. Ranges A and C met the NIOSH guidelines. Individual firing lane average air velocity measurements in Range A ranged 41-154 fpm, with an average across the firing line of $78 \mathrm{fpm}$ (Table C5). Average air velocity measurements for each firing lane in Range $C$ ranged $27-135 \mathrm{fpm}$, with an average of $78 \mathrm{fpm}$ across the firing line (Table C6). For Range B, we applied the NIOSH guidelines (minimum of $50 \mathrm{fpm}$ ) to each individual lane because the reactive steel range was a nontraditional layout. Average air velocity measurements within a firing lane in Range B ranged 0-148 fpm, with an average of $82 \mathrm{fpm}$ across the firing line (Table C7). Lanes 4 and 5 were not within NIOSH guidelines, which was likely due to an incorrectly aligned damper behind the firing line.

The facility adjusted the suspect damper inside the radial diffuser air supply behind Lanes 4 and 5 in Range B, and we repeated the air velocity measurements. After the adjustment, Range B was found to 
be within the NIOSH guidelines. Using the values measured after the adjustment, the air velocity measurements ranged 45-140 fpm within each firing lane and an average of $88 \mathrm{fpm}$ across the firing line (Table C8).

\section{Methods: Employee Health Assessment}

\section{Confidential Medical Interviews}

We invited all employees working during the initial site visit to participate in confidential medical interviews. The interviews consisted of questions about their work practices, work history, primary duties, lead-related medical history, possible nonoccupational sources of lead exposure, health symptoms, and workplace health and safety concerns.

\section{Occupational Medical Record Review}

We reviewed available BLL data for all employees. A case of elevated BLL was defined as an employee with a BLL $\geq 5$ micrograms per deciliter $(\mu \mathrm{g} / \mathrm{dL})$. This definition is consistent with the current case definition used by NIOSH's Adult Blood Lead Epidemiology and Surveillance (ABLES) program, the Council of State and Territorial Epidemiologists (CSTE), and the Centers for Disease Control and Prevention (CDC) National Notifiable Diseases Surveillance System [CDC 2016, 2018; CSTE 2015].

\section{Results: Employee Health Assessment}

\section{Confidential Medical Interviews}

We interviewed eight of the nine current employees. All employees were male with a median age of 41 (range: 27 to 59). Although the facility opened in May of 2017, the employees reported working at this facility a median of 12 months (range: 4 to 36 months). It is unclear why employees reported working at the facility longer than it has been in operation. Six of the employees reported having prior employment at other firing ranges or other facilities with exposure to lead. Job titles reported were general maintenance technician $(n=4)$, electronics technician $(n=2)$, lead technician $(n=1)$, and group lead $(n=1)$. All employees reported that they wore either a full-face respirator or a PAPR; they also reported being fit-tested and receiving respiratory protection training at least annually. All employees reported wearing nitrile gloves and a respirator when cleaning the range.

Three employees reported always changing into clean clothes and shoes prior to leaving work and never laundering work clothes at home (Table C9). The other five employees reported they did not change into clean clothes before leaving work, and they laundered their work clothes at home. Two employees reported showering prior to leaving the facility. Employees reported washing their hands with Hygenall ${ }^{\mathrm{TM}}$ lead removal soap a median of 6 times (range: 4 to 10) during a shift. Seven employees reported always washing their hands before eating.

Two employees reported having headaches and one employee reported tiredness during the last 3 months (Table C10). Six employees reported activities that may expose them to nonoccupational sources of lead, such as hunting or target practice $(n=3)$, remodeling old houses $(n=4)$, and doing auto body work $(n=1)$. All employees reported having a recent blood lead test and receiving the results. No employees had any workplace health and safety concerns.

B-6 


\section{Occupational Medical Record Review}

Employees receive BLL testing every six months. We reviewed the most recent BLL for all nine employees at the time of the initial visit. Two employees had results that met our case definition of elevated BLL of $\geq 5 \mu \mathrm{g} / \mathrm{dL}(5.3 \mu \mathrm{g} / \mathrm{dL}$ and $6.5 \mu \mathrm{g} / \mathrm{dL})$. No employees had a BLL at or above the DoD's medical removal level of $30 \mu \mathrm{g} / \mathrm{dL}$ [DoD 2018]. The two employees with the highest BLLs also had the highest lead personal air sample results on the first day of sampling. During the first day of sampling, employees participated in routine daily and weekly cleaning. Both employees had worked at the range for 12 months and reported not changing into clean clothes after a shift and laundering their work clothes at home. Neither employee reported any symptoms during the last 3 months that could be associated with lead exposure.

\section{Methods: Standard Operating Procedures and OSHA Log Review}

We reviewed the facility's written SOPs. We also attempted to review the OSHA Form 300 Log of Work-Related Injuries and Illnesses, but it was not available.

\section{Results: Standard Operating Procedures and OSHA Log Review}

The facility had written SOPs for all of the standard range cleaning and maintenance tasks. We reviewed those SOPs and found them to be comprehensive documents that were easily accessible in the office and administrative area of the range facility. Employees and management work with health and safety staff to update SOPs as needed based on observations, experiences, and sampling results.

Management informed us that OSHA Form 300 Logs did not exist because they did not have any recordable incidents at this facility. Additionally, the facility had not yet been in operation for more than one year.

\section{Discussion}

On Day one, we measured exposure to lead in the air while employees performed their weekly cleaning tasks. One employee's exposure exceeded the OSHA AL for lead. All other measurements were below all applicable OELs. The weekly task of cleaning the bullet trap ramp likely contributed to this employee's air sample being above the OSHA AL. When cleaning the ramps, employees stood on the ramp and used the floor mop to push debris toward the base of the ramp where the target line was. This action could re-suspend some lead dust in the air. Employees standing on the bullet trap ramp when it was being cleaned were required to wear respirators. All hand and shoe wipes were negative for lead, indicating that proper hand hygiene and wearing shoe covers were likely effective in reducing potential exposure.

On Day two, we measured exposure to lead in the air while employees were replacing exhaust fan prefilters and emptying the buckets at the bottom of the bullet trap of Range C. All employees' exposures exceeded the OSHA permissible exposure limit (PEL) for lead. We measured very high concentrations of lead, the maximum being $6,500 \mu \mathrm{g} / \mathrm{m}^{3}$, over about a three-hour period. The dusty nature of the tasks completed on this day likely contributed to the air samples exceeding the OSHA limit. 
Based on our personal air sampling results for lead (Table C2) and using NIOSH respiratory selection criteria, employees changing filters and emptying buckets should wear a higher level of respiratory protection than we observed during the site visit until further controls can be implemented to reduce airborne lead concentrations [NIOSH 2004]. The NIOSH APF for a hood PAPR is 25. Multiplying the NIOSH APF of 25 by the OEL for lead of $50 \mu \mathrm{g} / \mathrm{m}^{3}$ gives a maximum use concentration of $1,250 \mu \mathrm{g} / \mathrm{m}^{3}$. Because the airborne exposures to lead exceeded this maximum use concentration while changing prefilters and emptying buckets, a hood PAPR would not be sufficiently protective.

According to NIOSH, the adequate level of respiratory protection is a pressure-demand supplied-air respirator with a half-mask or a full facepiece. This respirator has a NIOSH APF of 1,000 (half-mask) or 2,000 (full facepiece) [NIOSH 2004]. The OSHA APF for a hood PAPR is also 25. However, this protection factor may be increased to 1,000. The employer must have evidence provided by the respirator manufacturer that testing of these respirators demonstrates performance at a level of protection of 1,000 or greater to receive an APF of 1,000 [OSHA 2009]. In this case, we were informed that the employer had documentation from the manufacturer that the PAPRs have an APF of 1,000. Therefore, the respiratory protection used during our site visit was allowable under the OSHA criteria but would not have been protective using NIOSH criteria. When concentrations are as high as the ones we measured on Day two, it is extremely important that employees don, doff, and wear PPE properly. Proper handling and use of PPE is essential to ensure that employees are protected while they are exposed to hazardous atmospheres.

The SOPs for cleaning and maintenance tasks were evolving as the facility usage increases. Management informed us that they expect range usage to increase and possibly double over the next year. We were informed that the facility plans to continue to change and adjust SOPs as needed based on changes in range usage. There seems to be a lack of consistent implementation of SOPs (e.g., issues with ripped gloves and suits) indicating a lack of training and practice with these procedures.

Some air velocity measurements were below the minimum recommended air velocity and were adjusted to bring the overall performance within NIOSH guidelines (Tables C5-C8). The final air velocity data collected indicate the ventilation system was operating within NIOSH guidelines. It is important to perform periodic checks of air velocity to identify and correct potential problems.

There are no OELs for surface contamination. Overall, we found lower levels of lead contamination in this facility as compared with a previous health hazard evaluation in another firing range [NIOSH 2017a]. Surface contamination levels were similar to those of a previously evaluated range with comparable approaches to reducing contamination [NIOSH 2017b]. The chair in the maintenance room we sampled had the highest surface contamination of any of our wipe samples $(370 \mu \mathrm{g}$ lead/100 $\mathrm{cm}^{2}$ ), even though our sampling was performed after the chair was decontaminated by an employee using a lead removal wipe. A plausible reason for the chair contamination may be because employees roll the chairs around the area behind the bullet trap while emptying the buckets to avoid frequent bending and twisting. Once the buckets were emptied, employees wiped the chairs with lead removal wipes prior to removing them from the bullet trap area. The material that the chair was made of (a textured rubber-like material) likely trapped some lead and reduced the effectiveness of the cleaning wipe. With the exception of the maintenance room chair and cart handle on Range C, most of 
the lead wipe samples we collected throughout the facility were either below or very close to the analytical method's limit of quantification.

According to the DoD, employees who are exposed to $30 \mu \mathrm{g} / \mathrm{m}^{3}$ of lead for 30 days a year (OSHA's AL) require annual BLL testing [DoD 2018]. Employees with BLLs at or above $20 \mu \mathrm{g} / \mathrm{dL}$ are required to have a repeat test performed in 4 weeks ( 1 month) and to receive written notification within 5 days after the medical provider gets the BLL results [DoD 2018]. The DoD also requires the employee be removed from lead exposure if a single test result is at or above $30 \mu \mathrm{g} / \mathrm{dL}$, and that their supervisor be notified to remove the employee from lead exposure if repeat BLL testing is at or above $20 \mu \mathrm{g} / \mathrm{dL}$ in 4 weeks. After removal from lead exposure, employees may only return to working with lead after two BLLs, done one month apart, are at or below $15 \mu \mathrm{g} / \mathrm{dL}$. This process is more protective than OSHA's lead standard.

Although no workers met the DoD criteria for removal from work or required repeat testing, two employees did have BLLs above $5 \mu \mathrm{g} / \mathrm{dL}$. In 2015, NIOSH used this BLL to define the term "elevated." According to the National Toxicology Program (NTP), there is sufficient evidence that adverse health effects, such as increased blood pressure, increased risk for hypertension, and increased incidence of essential tremor, can occur in adults at BLLs less than $10 \mu \mathrm{g} / \mathrm{dL}$ [NTP 2012]. Therefore, it is important to continue monitoring employees' BLLs and to document any health effects that they may report.

\section{Limitations}

This evaluation is subject to several limitations. First, industrial hygiene sampling can only document exposures on the days of sampling in the locations sampled. These results may not be representative of exposures during other days. Management told us that the amount of work performed in the facility was expected to increase and even double over the coming year. In addition, the small size and homogenous nature of the population sampled limit the generalizability of our evaluation results. Because the interviews and questionnaires asked employees about past workplace processes, practices, and conditions; exposures; and health effects, these results are subject to recall bias. We did not directly evaluate the ventilation system in Range $\mathrm{C}$, but relied on data provided to us by health and safety staff. Finally, if there is a nonoccupational exposure to lead that occurs away from work, the contribution of that exposure would not be captured by our air sampling effort, but would potentially add to the lead found in blood.

\section{Conclusions}

Four employees had lead exposures that were above the OSHA PEL when changing prefilters and emptying the bullet trap buckets. Employees wore respiratory protection while performing these tasks. NIOSH respirator selection guidance recommends a higher level of protection given the high lead concentrations we measured when employees were cleaning the bullet trap and replacing prefilters. Employees may benefit from performing these tasks on different days to lessen their daily exposure. One employee was above the OSHA AL for lead while preforming daily and weekly cleaning. Only two employees had elevated BLLs $(>5 \mu \mathrm{g} / \mathrm{dL})$. Surface contamination with lead was generally similar, and sometimes lower, than concentrations we have measured in previous evaluations of firing ranges 
[NIOSH 2017a,b]. The ventilation system appeared to be operating according to NIOSH guidelines. Although all employees were being monitored through the medical surveillance program and received training on lead exposure, they may benefit from more training on take-home lead. More guidance, training, and attention to the SOPs regarding what action needs to be taken if one's suit or glove rips or becomes compromised appears warranted. 


\section{Section C: Tables}

Table C1. Day one full-shift personal air sampling results for lead and copper $\left(\mu \mathrm{g} / \mathrm{m}^{3}\right)$

\begin{tabular}{cccc}
\hline Employee & $\begin{array}{c}\text { Sample duration } \\
\text { (minutes) }^{*}\end{array}$ & Lead & Copper \\
\hline Employee 1 & 459 & 4.3 & 310 \\
Employee 2 & 458 & 5.1 & 130 \\
Employee 3 & 468 & $36 \dagger$ & 12 \\
Employee 4 & 224 & 2.8 & 5.1 \\
Employee 5 & 438 & 10 & 280 \\
Employee 6 & 475 & 0.15 & 0.61 \\
Employee 7 & 458 & 0.31 & 0.29 \\
\hline NIOSH recommended exposure limit (REL) & 50 & 1,000 \\
OSHA permissible exposure limit (PEL) & 50 & 1,000 \\
ACGIH threshold limit value (TLV) & 50 & 1,000 \\
\hline
\end{tabular}

*Employees' shift length varied. We sampled each employee for their entire shift.

†This value exceeds the OSHA action level of $30 \mu \mathrm{g} / \mathrm{m}^{3}$.

Table C2. Day two personal air sampling results for lead and copper $\left(\mu \mathrm{g} / \mathrm{m}^{3}\right)$

\begin{tabular}{cccccc}
\hline Employee & $\begin{array}{c}\text { Sample duration } \\
\text { (minutes) }\end{array}$ & \multicolumn{2}{c}{ Lead } & \multicolumn{3}{c}{ Copper } \\
\cline { 3 - 6 } & & Task & 8-hr TWA & Task & 8-hr TWA \\
\hline Employee 1 & 131 & 4,200 & 1,100 & 390 & 110 \\
Employee 2 & 119 & 6,000 & 1,500 & 220 & 55 \\
Employee 3 & 175 & 6,500 & 2,400 & 340 & 120 \\
Employee 4 & 186 & 57 & 22 & 810 & 310 \\
Employee 5 & 187 & 1,800 & 700 & 240 & 94 \\
\hline NIOSH REL & & - & 50 & - & 1,000 \\
OSHA PEL & & - & 50 & - & 1,000 \\
ACGIH TLV & & - & 50 & - & 1,000
\end{tabular}

*Employees only changed prefilters and emptied buckets behind the bullet trap on this day. We sampled each employee for the entire duration of those tasks.

†This value was calculated assuming zero exposure for the remainder of an 8-hr day. Employees left the workplace after completing these tasks. 
Table C3. Comparison of the effective lead concentrations $\left(\mu \mathrm{g} / \mathrm{m}^{3}\right)$ that employees were exposed to after applying NIOSH and OSHA respirator APFs

\begin{tabular}{ccc|cc}
\hline \multirow{2}{*}{ Employee } & \multicolumn{2}{c|}{ Task TWA } & \multicolumn{2}{c}{ 8-hr TWA } \\
\cline { 2 - 5 } & NIOSH APF 25 & OSHA APF 1,000 & NIOSH APF 25 & OSHA APF 1,000 \\
\hline Employee 1 & 168 & 4.2 & 46 & 1.1 \\
Employee 2 & 240 & 6 & 60 & 1.5 \\
Employee 3 & 260 & 6.5 & 95 & 2.4 \\
Employee 4 & 2.3 & 0.057 & 0.88 & 0.022 \\
Employee 5 & 72 & 1.8 & 28 & 0.7 \\
\hline
\end{tabular}


Table C4. Surface wipe sample results $\left(\mu \mathrm{g} / 100 \mathrm{~cm}^{2}\right)$

\begin{tabular}{|c|c|c|}
\hline Location & Lead* $^{*}$ & Copper† \\
\hline \multicolumn{3}{|l|}{ Maintenance room } \\
\hline Maintenance room chair back & 370 & 150 \\
\hline Ventilation system monitoring laptop & {$[0.8]$} & [2.6] \\
\hline Employee locker handle & 2.1 & 51 \\
\hline Washing machine top & 1.9 & 100 \\
\hline Microwave keypad & [1.1] & [2.1] \\
\hline \multicolumn{3}{|l|}{ Range A } \\
\hline Control room table & {$[0.65]$} & {$[1.7]$} \\
\hline Inside handle of control room door & [1.3] & [1.4] \\
\hline Sink faucet, both handles & 6.2 & 16 \\
\hline Push bar, main exit & 3 & 4.5 \\
\hline Work bench inside range & [1.4] & [2.3] \\
\hline Handle of bullet casing sweeper & 35 & 110 \\
\hline \multicolumn{3}{|l|}{ Range B } \\
\hline Control room table (1) & [0.96] & 17 \\
\hline Control room table (2) & 7.7 & 310 \\
\hline Door push bar, main exit & {$[1.5]$} & 23 \\
\hline Lane 3 control panel & [0.69] & 8.8 \\
\hline Lane 4 control panel & 2.1 & 16 \\
\hline \multicolumn{3}{|l|}{ Range C } \\
\hline Control room table & {$[1.2]$} & [1.1] \\
\hline Control room keyboard & 6.7 & 21 \\
\hline Push bar, main exit & 3.9 & {$[4.2]$} \\
\hline Sink faucet, both handles & 3.3 & 24 \\
\hline Cart handle, on range & 110 & 290 \\
\hline \multicolumn{3}{|l|}{ Office/classroom areas } \\
\hline Office keyboard wrist rest & 13 & 39 \\
\hline Office break room counter & Not detected & [1.1] \\
\hline Classroom desktop & [0.69] & Not detected \\
\hline Classroom floor, door to room & {$[0.9]$} & [2.5] \\
\hline Office building floor, just inside entrance & 2.6 & 11 \\
\hline
\end{tabular}

[ ] = Estimated concentration: this concentration was between the minimum detectable and minimum quantifiable concentrations.

*For lead, the limit of detection was $0.5 \mu \mathrm{g} / 100 \mathrm{~cm}^{2}$, while the limit of quantification was $1.7 \mu \mathrm{g} / 100 \mathrm{~cm}^{2}$. †For copper, the limit of detection was $1 \mu \mathrm{g} / 100 \mathrm{~cm}^{2}$, while the limit of quantification was $4.2 \mu \mathrm{g} / \mathrm{m}^{2}$. 
Table C5. Minimum, maximum, and average air velocities (fpm) for each firing line in Range A

\begin{tabular}{|c|c|c|c|c|}
\hline Firing line: & 3 yard line & 7 yard line & 15 yard line & 25 yard line \\
\hline Minimum velocity & $41^{*}$ & 50 & $44^{*}$ & $40^{*}$ \\
\hline Maximum velocity & 105 & 110 & 110 & 154 \\
\hline Average velocity & 75 & 77 & 75 & 84 \\
\hline
\end{tabular}

The air velocities were not measured along the 10 yard line.

*Value is below NIOSH guideline of $50 \mathrm{fpm}$.

Table C6. Minimum, maximum, and average air velocities (fpm) for each firing lane in Range $\mathrm{C}$ measured by the facility after our visit

\begin{tabular}{lccccc}
\hline Firing line: & 3 yard line & 7 yard line & 15 yard line & 25 yard line & 50 yard line \\
\hline Minimum velocity & 53 & $48^{\star}$ & $27^{\star}$ & $47^{\star}$ & 65 \\
Maximum velocity & 116 & 91 & 95 & 108 & 135 \\
Average velocity & 81 & 64 & 63 & 78 & 103 \\
\hline
\end{tabular}

The air velocities were not measured along the 10 yard line.

*Value is below NIOSH guideline of $50 \mathrm{fpm}$.

Table C7. Minimum, maximum, and average air velocities (fpm) for each firing lane in Range B (before damper adjustment)

\begin{tabular}{lcccccc}
\hline Firing lane: & Lane 1 & Lane 2 & Lane 3 & Lane 4 & Lane 5 & Lane 6 \\
\hline Minimum velocity & 61 & 54 & 61 & $0^{*}$ & $32^{*}$ & $45^{*}$ \\
Maximum velocity & 102 & 104 & 92 & 148 & 128 & 127 \\
Average velocity & 92 & 80 & 77 & 71 & 77 & 94 \\
\hline
\end{tabular}

*Value is below NIOSH guideline of $50 \mathrm{fpm}$. 
Table C8. Minimum, maximum, and average air velocities (fpm) for each firing lane in Range B (after damper adjustment)

\begin{tabular}{lcccccc}
\hline Firing lane: & Lane 1 & Lane 2 & Lane 3 & Lane 4 & Lane 5 & Lane 6 \\
\hline Minimum velocity & 67 & 54 & 61 & 59 & $45^{\star}$ & 57 \\
Maximum velocity & 102 & 104 & 92 & 135 & 133 & 140 \\
Average velocity & 92 & 80 & 76 & 80 & 91 & 109 \\
\hline
\end{tabular}

*Value is below NIOSH guideline of $50 \mathrm{fpm}$.

Table C9. Frequency of hygiene practices reported by interviewed workers $(n=8)$

\begin{tabular}{lc}
\hline Hygiene practice & $\begin{array}{c}\text { Number of } \\
\text { workers }\end{array}$ \\
\hline $\begin{array}{l}\text { Always change into clean clothes prior to } \\
\text { leaving worksite }\end{array}$ & 3 \\
Shower at work prior to leaving worksite & 2 \\
Launder any work clothes at home & 5 \\
Always washes hands prior to eating & 7 \\
\hline
\end{tabular}

Table C10. Symptoms within the past 3 months reported by interviewed workers that could be associated with lead exposure $(n=8)$

\begin{tabular}{lc}
\hline Symptom & $\begin{array}{c}\text { Number of } \\
\text { workers }\end{array}$ \\
\hline Headache & 2 \\
Dizziness & 0 \\
Numbness or tingling in hands or feet & 0 \\
Unexplained pain in stomach & 0 \\
Joint pain & 0 \\
Tiredness & 1 \\
Feeling nervous & 0 \\
Nightmares or strange dreams & 0 \\
Problems concentrating & 0 \\
\hline
\end{tabular}




\section{Section D: Occupational Exposure Limits}

NIOSH investigators refer to mandatory (legally enforceable) and recommended OELs for chemical, physical, and biological agents when evaluating workplace hazards. OELs have been developed by federal agencies and safety and health organizations to prevent adverse health effects from workplace exposures. Generally, OELs suggest levels of exposure that most employees may be exposed to for up to 10 hours per day, 40 hours per week, for a working lifetime, without experiencing adverse health effects.

However, not all employees will be protected if their exposures are maintained below these levels. Some may have adverse health effects because of individual susceptibility, a preexisting medical condition, or a hypersensitivity (allergy). In addition, some hazardous substances act in combination with other exposures, with the general environment, or with medications or personal habits of the employee to produce adverse health effects. Most OELs address airborne exposures, but some substances can be absorbed directly through the skin and mucous membranes.

Most OELs are expressed as a TWA exposure. A TWA refers to the average exposure during a normal 8- to 10-hour workday. Some chemical substances and physical agents have recommended short-term exposure limits (STEL) or ceiling values. Unless otherwise noted, the STEL is a 15-minute TWA exposure. It should not be exceeded at any time during a workday. The ceiling limit should not be exceeded at any time.

In the United States, OELs have been established by federal agencies, professional organizations, state and local governments, and other entities. Some OELs are legally enforceable limits; others are recommendations.

- OSHA, an agency of the U.S. Department of Labor, publishes permissible exposure limits [29 CFR 1910 for general industry; 29 CFR 1926 for construction industry; and 29 CFR 1917 for maritime industry] called PELs. These legal limits are enforceable in workplaces covered under the Occupational Safety and Health Act of 1970.

- NIOSH RELs are recommendations based on a critical review of the scientific and technical information and the adequacy of methods to identify and control the hazard. NIOSH RELs are published in the NIOSH Pocket Guide to Chemical Hazards [NIOSH 2007]. NIOSH also recommends risk management practices (e.g., engineering controls, safe work practices, employee education/training, PPE, and exposure and medical monitoring) to minimize the risk of exposure and adverse health effects.

- Another set of OELs commonly used and cited in the United States include the threshold limit values or TLVs, which are recommended by ACGIH. The ACGIH TLVs are developed by committee members of this professional organization from a review of the published, peerreviewed literature. TLVs are not consensus standards. They are considered voluntary exposure guidelines for use by industrial hygienists and others trained in this discipline "to assist in the control of health hazards" [ACGIH 2019].

D-1 
Outside the United States, OELs have been established by various agencies and organizations and include legal and recommended limits. The Institut für Arbeitsschutz der Deutschen Gesetzlichen Unfallversicherung (Institute for Occupational Safety and Health of the German Social Accident Insurance) maintains a database of international OELs from European Union member states, Canada (Québec), Japan, Switzerland, and the United States. The database, available at https://www.dguv.de/ifa/gestis/gestis-stoffdatenbank/index-2.jsp, contains international limits for more than 2,000 hazardous substances and is updated periodically.

OSHA (Public Law 91-596) requires an employer to furnish employees a place of employment free from recognized hazards that cause or are likely to cause death or serious physical harm. This is true in the absence of a specific OEL. It also is important to keep in mind that OELs may not reflect current health-based information.

When multiple OELs exist for a substance or agent, NIOSH investigators generally encourage employers to use the lowest OEL when making risk assessment and risk management decisions.

\section{Copper Particulate (as Fume or Dust/Mist)}

Copper is a widely used metal that is capable of forming numerous alloys. One of copper's potential uses is to form an alloy using zinc that is used to produce frangible ammunition. Based on the measurements from this evaluation, under weapon firing conditions of high heat, pressure, and mechanical abrasion, copper-based frangible ammunition can produce fume and nano-sized and larger particulate.

\section{Occupational Exposure Limits}

The OSHA PEL and the NIOSH REL for copper fume is $0.1 \mathrm{mg} / \mathrm{m}^{3}$ and $1 \mathrm{mg} / \mathrm{m}^{3}$ as a dust or mist [NIOSH 2007]. The ACGIH TLV is $0.2 \mathrm{mg} / \mathrm{m}^{3}$ for the fume and $1 \mathrm{mg} / \mathrm{m}^{3}$ for the dust or mist [ACGIH 2019].

\section{Health Effects}

Health effects from copper fume consist of upper respiratory irritation, metallic taste, nausea, metal fume fever, and possibly discoloration of the hair and skin [ACGIH 2011]. One study identified a condition similar to metal fume fever in workers exposed to metallic copper dust in concentrations on the order of $0.1 \mathrm{mg} / \mathrm{m}^{3}$ [Gleason 1968].

\section{Lead}

Inorganic lead is a naturally occurring, soft metal that has been mined and used in industry since ancient times. It comes in many forms (e.g., lead acetate, lead chloride, lead chromate, lead nitrate, lead oxide, lead phosphate, and lead sulfate). Lead is considered toxic to all organ systems and serves no useful purpose in the body.

Occupational exposure to inorganic lead occurs via inhalation of lead-containing dust and fume and ingestion of lead particles from contact with lead-contaminated surfaces. Exposure may also occur through transfer of lead to the mouth from contaminated hands or cigarettes when careful attention to hygiene, particularly handwashing, is not practiced. In addition to the inhalation and ingestion routes of 
exposure, lead can be absorbed through the skin, particularly through damaged skin [Filon et al. 2006; Stauber et al. 1994; Sun et al. 2002].

Workplace settings with exposure to lead and lead compounds include smelting and refining, scrap metal recovery, automobile radiator repair, construction and demolition (including abrasive blasting), and firing ranges. Occupational exposures also occur among workers who apply or remove lead-based paint and among welders who burn or torch-cut metal structures.

\section{Blood Lead Levels}

In most cases, an individual's BLL is a good indication of recent exposure to lead because the half-life of lead (the time interval it takes for the quantity in the body to be reduced by half its initial value) is 1-2 months [CDC 2013a; Lauwerys and Hoet 2001; Moline and Landrigan 2005]. Most lead in the body is stored in the bones, with a half-life of years to decades. Measuring bone lead, however, is primarily done only for research. Elevated zinc protoporphyrin levels have also been used as an indicator of chronic lead intoxication. Because other factors, such as iron deficiency, can cause an elevated zinc protoporphyrin level, monitoring the BLL over time is more specific for evaluating chronic occupational lead exposure.

BLLs in adults in the United States have declined consistently over time. The average geometric mean BLL of all adults in 2009-2010 was $1.2 \mu \mathrm{g} / \mathrm{dL}$ [CDC 2018]. The NIOSH ABLES program uses a surveillance case definition for an elevated BLL in adults of $5 \mu \mathrm{g} / \mathrm{dL}$ of blood or higher [CDC 2018]. Very high BLLs are defined as BLLs $\geq 40 \mu \mathrm{g} / \mathrm{dL}$. From 2002-2011, occupational exposures accounted for $91 \%$ of adults with very high BLLs (where exposure source was known) [CDC 2013b]. This underscores the need to increase efforts to prevent lead exposures in the workplace.

\section{Occupational Exposure Limits}

In the United States, employers in general industry are required by law to follow the OSHA lead standard [29 CFR 1910.1025]. This standard was established in 1978 and has not yet been updated to reflect the current scientific knowledge regarding the health effects of lead exposure.

Under this standard, the PEL for airborne exposure to lead is $50 \mu \mathrm{g} / \mathrm{m}^{3}$ of air for an 8-hour TWA. The standard requires lowering the PEL for shifts that exceed 8 hours, medical monitoring for employees exposed to airborne lead at or above the OSHA AL of $30 \mu \mathrm{g} / \mathrm{m}^{3}$ (8-hour TWA), medical removal of employees whose average BLL is $50 \mu \mathrm{g} / \mathrm{dL}$ or greater, and economic protection for medically removed workers. Medically removed workers cannot return to jobs involving lead exposure until their BLL is below $40 \mu \mathrm{g} / \mathrm{dL}$.

In the United States, other guidelines for lead exposure, which are not legally enforceable, are often followed. Similar to the OSHA lead standard, these guidelines were set years ago and have not yet been updated to reflect current scientific knowledge. NIOSH has a REL for lead of $50 \mu \mathrm{g} / \mathrm{m}^{3}$ averaged over an 8-hour work shift [NIOSH 2007]. The ACGIH has a TLV for lead of $50 \mu \mathrm{g} / \mathrm{m}^{3}$ (8-hour TWA), with worker BLLs to be controlled to, or below, $30 \mu \mathrm{g} / \mathrm{dL}$. The ACGIH designates lead as an animal carcinogen [ACGIH 2019]. In 2013, the California Department of Public Health recommended that Cal/OSHA lower the PEL for lead to 0.5 to $2.1 \mu \mathrm{g} / \mathrm{m}^{3}$ (8-hour TWA) to keep BLLs below the range of 5 to $10 \mu \mathrm{g} / \mathrm{dL}$ [Billingsley 2013]. 
Neither NIOSH nor OSHA has established surface contamination limits for lead in the workplace. The U.S. Environmental Protection Agency and the U.S. Department of Housing and Urban Development limit lead on surfaces in public buildings and child-occupied housing to less than 40 micrograms of lead per square foot [EPA 1998; HUD 2012]. OSHA requires in its substance-specific standard for lead that all surfaces be maintained as free as practicable of accumulations of lead [29 CFR 1910.1025(h)(1)]. An employer with workplace exposures to lead must implement regular and effective cleaning of surfaces in areas such as change areas, storage facilities, and lunchroom/eating areas to ensure they are as free as practicable from lead contamination.

\section{Health Effects}

The PEL, REL, and TLV may prevent overt symptoms of lead poisoning, but do not protect workers from lead's contributions to conditions such as hypertension, renal dysfunction, reproductive, and cognitive effects [Brown-Williams et al. 2009; Institute of Medicine 2012; Schwartz and Hu 2007;

Schwartz and Stewart 2007]. Generally, acute lead poisoning with symptoms has been documented in persons having BLLs above $70 \mu \mathrm{g} / \mathrm{dL}$. These BLLs are rare today in the United States, largely as a result of workplace controls put in place to comply with current occupational exposure limits. When present, acute lead poisoning can cause myriad adverse health effects including abdominal pain, hemolytic anemia, and neuropathy. Lead poisoning has, in very rare cases, progressed to encephalopathy and coma [Moline and Landrigan 2005].

People with chronic lead poisoning, which is more likely at current occupational exposure levels, may not have symptoms or they may have nonspecific symptoms that may not be recognized as being associated with lead exposure. These symptoms include headache, joint and muscle aches, weakness, fatigue, irritability, depression, constipation, anorexia, and abdominal discomfort [Moline and Landrigan 2005].

The NTP recently released a monograph on the health effects of low-level lead exposure [NTP 2012]. For adults, the NTP concluded the following about the evidence regarding health effects of lead (Table D1). 
Table D1. Evidence regarding health effects of lead in adults

\begin{tabular}{|c|c|c|c|}
\hline Health area & NTP conclusion & Principal health effects & Blood lead evidence \\
\hline \multirow[t]{3}{*}{ Neurological } & Sufficient & Increased incidence of essential tremor & Yes, $<10 \mu \mathrm{g} / \mathrm{dL}$ \\
\hline & Limited & $\begin{array}{l}\text { Psychiatric effects, decreased hearing, } \\
\text { decreased cognitive function, increased } \\
\text { incidence of amyotrophic lateral sclerosis }\end{array}$ & Yes, $<10 \mu \mathrm{g} / \mathrm{dL}$ \\
\hline & Limited & Increased incidence of essential tremor & Yes, $<5 \mu \mathrm{g} / \mathrm{dL}$ \\
\hline Immune & Inadequate & & Unclear \\
\hline \multirow[t]{2}{*}{ Cardiovascular } & Sufficient & $\begin{array}{l}\text { Increased blood pressure and } \\
\text { increased risk of hypertension }\end{array}$ & Yes, $<10 \mu \mathrm{g} / \mathrm{dL}$ \\
\hline & Limited & $\begin{array}{l}\text { Increased cardiovascular-related mortality } \\
\text { and electrocardiography abnormalities }\end{array}$ & Yes, $<10 \mu \mathrm{g} / \mathrm{dL}$ \\
\hline Renal & Sufficient & Decreased glomerular filtration rate & Yes, $<5 \mu \mathrm{g} / \mathrm{dL}$ \\
\hline \multirow[t]{6}{*}{ Reproductive } & Sufficient & Women: reduced fetal growth & Yes, $<5 \mu \mathrm{g} / \mathrm{dL}$ \\
\hline & Sufficient & $\begin{array}{l}\text { Men: adverse changes in sperm parameters } \\
\text { and increased time to pregnancy }\end{array}$ & Yes, $\geq 15-20 \mu \mathrm{g} / \mathrm{dL}$ \\
\hline & Limited & $\begin{array}{c}\text { Women: increase in spontaneous abortion } \\
\text { and preterm birth }\end{array}$ & Yes, $<10 \mu \mathrm{g} / \mathrm{dL}$ \\
\hline & Limited & Men: decreased fertility & Yes, $\geq 10 \mu \mathrm{g} / \mathrm{dL}$ \\
\hline & Limited & Men: spontaneous abortion & Yes, $\geq 31 \mu \mathrm{g} / \mathrm{dL}$ \\
\hline & Inadequate & $\begin{array}{l}\text { Women and Men: stillbirth, endocrine effects, } \\
\text { birth defects }\end{array}$ & Unclear \\
\hline
\end{tabular}

Various organizations have assessed the relationship between lead exposure and cancer. According to the Agency for Toxic Substances and Disease Registry [ATSDR 2007] and the NTP [NTP 2011], inorganic lead compounds are reasonably anticipated to cause cancer in humans. The International Agency for Research on Cancer classifies inorganic lead as probably carcinogenic to humans [IARC 2006]. According to the American Cancer Society (ACS) [ACS 2011], some studies show a relationship between lead exposure and lung cancer, but these results might be affected by exposure to cigarette smoking and arsenic. Some studies show a relationship between lead and stomach cancer, and these findings are less likely to be affected by the other exposures. The results of studies looking at other cancers, including brain, kidney, bladder, colon, and rectum, are mixed.

\section{Medical Management}

To prevent acute and chronic health effects, a panel of experts convened by the Association of Occupational and Environmental Clinics published guidelines for the management of adult lead exposure [Kosnett et al. 2007]. The panel recommended BLL testing for all lead-exposed employees, regardless of the airborne lead concentration. These recommendations do not apply to pregnant women, who should avoid BLLs $>5 \mu \mathrm{g} / \mathrm{dL}$. Removal from lead exposure should be considered if control measures over an extended period do not decrease BLLs to $<10 \mu \mathrm{g} / \mathrm{dL}$ or an employee has a medical condition that would increase the risk of adverse health effects from lead exposure. These guidelines were endorsed by the Council of State and Territorial Epidemiologists and the California Department of Public Health in 2009 and the American College of Occupational and Environmental 
Medicine in 2010 [ACOEM 2010; CDPH 2009; CSTE 2009]. The Council of State and Territorial Epidemiologists published updated guidelines in 2013 to reflect the new definition of an elevated BLL in adults of $5 \mu \mathrm{g} / \mathrm{dL}$ [CSTE 2013]. The California Department of Public Health recommended keeping BLLs below 5 to $10 \mu \mathrm{g} / \mathrm{dL}$ in 2013 [Billingsley 2013] and updated their medical management guidelines in 2014 [CDPH 2014]. In 2015, NIOSH designated $5 \mu \mathrm{g} / \mathrm{dL}$ of whole blood, in a venous blood sample, as the reference BLL for adults. An elevated BLL is defined as a BLL $\geq 5 \mu \mathrm{g} / \mathrm{dL}$. Table D2 incorporates recommendations from the expert panel guidelines and those from CDPH and CSTE.

Table D2. Health-based medical surveillance recommendations for lead-exposed employees

\begin{tabular}{|c|c|}
\hline Category of exposure & Recommendations \\
\hline $\begin{array}{l}\text { All lead exposed } \\
\text { workers }\end{array}$ & $\begin{array}{l}\text { Baseline or preplacement medical history and physical examination, baseline } \\
\text { BLL, and serum creatinine }\end{array}$ \\
\hline $\mathrm{BLL}<5 \mu \mathrm{g} / \mathrm{dL}$ & $\begin{array}{l}\text { BLL monthly for first } 3 \text { months placement, or upon change in task to higher } \\
\text { exposure, then BLL every } 6 \text { months; if } B L L \text { increases } \geq 5 \mu \mathrm{g} / \mathrm{dL} \text {, evaluate } \\
\text { exposure and protective measures, and increase monitoring if indicated }\end{array}$ \\
\hline BLL $5-9 \mu \mathrm{g} / \mathrm{dL}$ & $\begin{array}{l}\text { - Discuss health risks } \\
\text { - } \text { Minimize exposure } \\
\text { - } \text { Consider removal for pregnancy and certain medical conditions } \\
\text { BLL monthly for first } 3 \text { months placement or every } 2 \text { months for the first } \\
\text { every } 6 \text { months; if BLL increases } \geq 5 \mu \mathrm{g} / \mathrm{dL} \text {, evaluate exposure, then } \mathrm{BLL} \\
\text { measures, and increase monitoring if indicated }\end{array}$ \\
\hline BLL $10-19 \mu \mathrm{g} / \mathrm{dL}$ & $\begin{array}{l}\text { - } \text { Discuss health risks } \\
\text { - } \text { Decrease exposure } \\
\text { - } \text { Remove from exposure for pregnancy } \\
\text { - } \text { Consider removal for certain medical conditions or BLL } \geq 10 \mu \mathrm{g} / \mathrm{dL} \text { for } \\
\text { extended period } \\
\text { BLL every } 3 \text { months; evaluate exposure, engineering controls, and work } \\
\text { practices; consider removal. } \\
\text { - Revert to BLL every } 6 \text { months after } 3 \mathrm{BLLs}<10 \mu \mathrm{g} / \mathrm{dL}\end{array}$ \\
\hline BLL 20-29 $\mu \mathrm{g} / \mathrm{dL}$ & $\begin{array}{l}\text { - Remove from exposure for pregnancy } \\
\text { - Remove from exposure if repeat BLL measured in } 4 \text { weeks remains } \geq 20 \mu \mathrm{g} / \mathrm{dL} \\
\text { - } \text { Annual lead medical exam recommended } \\
\text { - } \text { Monthly BLL testing } \\
\text { - Consider return to work after } 2 \mathrm{BLLs}<15 \mu \mathrm{g} / \mathrm{dL} \text { a month apart, then monitor as } \\
\text { above }\end{array}$ \\
\hline BLL 30-49 $\mu \mathrm{g} / \mathrm{dL}$ & $\begin{array}{l}\text { - Remove from exposure } \\
\text { - Prompt medical evaluation } \\
\text { - } \text { Monthly BLL testing } \\
\text { - } \text { Consider return to work after } 2 \mathrm{BLLs}<15 \mu \mathrm{g} / \mathrm{dL} \text { a month apart, then monitor as } \\
\text { above }\end{array}$ \\
\hline BLL $50-79 \mu \mathrm{g} / \mathrm{dL}$ & $\begin{array}{l}\text { - Remove from exposure } \\
\text { - } \text { Prompt medical evaluation } \\
\text { - } \text { Consider chelation with significant symptoms }\end{array}$ \\
\hline $\mathrm{BLL} \geq 80 \mu \mathrm{g} / \mathrm{dL}$ & $\begin{array}{ll}\text { - } & \text { Remove from exposure } \\
\text { - } & \text { Urgent medical evaluation } \\
\text { - } & \text { Chelation may be indicated }\end{array}$ \\
\hline
\end{tabular}

Adapted from Kosnett et al. 2007, CSTE 2013, and CDPH 2014

D-6 


\section{Take-home Contamination}

Occupational exposures to lead can result in exposures to household members, including children, from take-home contamination. Take-home contamination occurs when lead dust is transferred from the workplace on employees' skin, clothing, shoes, and other personal items to their vehicle and home [CDC 2009, 2012]. The CDC considers a BLL in children of $5 \mu \mathrm{g} / \mathrm{dL}$ or higher as a reference level above which public health actions should be initiated, and states that no safe BLL in children has been identified [CDC 2013a].

The U.S. Congress passed the Workers' Family Protection Act in 1992 (29 U.S.C. 671a). The Act required NIOSH to study take-home contamination from workplace chemicals and substances, including lead. NIOSH found that take-home exposure is a widespread problem [NIOSH 1995]. Workplace measures effective in preventing take-home exposures were (1) reducing exposure in the workplace, (2) changing clothes before going home and leaving soiled clothing at work for laundering, (3) storing street clothes in areas separate from work clothes, (4) showering before leaving work, and (5) prohibiting removal of toxic substances or contaminated items from the workplace. NIOSH noted that preventing take-home exposure is critical because decontaminating homes and vehicles is not always effective. Normal house cleaning and laundry methods are inadequate, and decontamination can expose the people doing the cleaning and laundry. 


\section{Section E: References}

\section{Methods}

NIOSH [2019]. NIOSH manual of analytical methods (NMAM). 5th ed. O’Connor PF, Ashley K, eds. Cincinnati, OH: U.S. Department of Health and Human Services, Centers for Disease Control and Prevention, National Institute for Occupational Safety and Health, DHHS (NIOSH) Publication No. 2014-151, http://www.cdc.gov/niosh/nmam.

\section{Discussion}

NIOSH [2004]. NIOSH respirator selection logic. Bollinger N. Cincinnati, OH: U.S. Department of Health and Human Services, Centers for Disease Control and Prevention, National Institute for Occupational Safety and Health, DHHS (NIOSH) Publication No. 2005-100, https://doi.org/10.26616/nioshpub2005100.

NIOSH [2017a]. Evaluation of lead exposure at an indoor law enforcement firing range. By Grant MP, Eisenberg J, Methner M. Cincinnati, OH: U.S. Department of Health and Human Services, Centers for Disease Control and Prevention, National Institute for Occupational Safety and Health, Health Hazard Evaluation Report 2016-0232-3285, http://www.cdc.gov/niosh/hhe/reports/pdfs/2016-02323285.pdf.

NIOSH [2017b]. Evaluation of ventilation and employee exposures to lead at an indoor firing range. By Methner MM. Cincinnati, OH: U.S. Department of Health and Human Services, Centers for Disease Control and Prevention, National Institute for Occupational Safety and Health, Health Hazard Evaluation Report 2016-0079-3289, https://www.cdc.gov/niosh/hhe/reports/pdfs/2016-00793289.pdf.

OSHA [2009]. Assigned protection factors for the revised respiratory protection standard. Bollinger N. Cincinnati, OH: U.S. Department of Labor, Occupational Safety and Health Administration, OSHA Publication No. 3352-02, https://www.osha.gov/Publications/3352-APF-respirators.pdf.

\section{Copper}

ACGIH [2011]. Documentation of threshold limit values and biological exposure indices. Cincinnati, OH: American Conference of Governmental Industrial Hygienists. ISBN: 978-1-607260-28-8.

ACGIH [2019]. 2019 TLVs $^{\circledR}$ and BEIs ${ }^{\circledR}$ : threshold limit values for chemical substances and physical agents and biological exposure indices. Cincinnati, OH: American Conference of Governmental Industrial Hygienists.

Gleason RP [1968]. Exposure to copper dust. Am Ind Hyg Assoc J 29(5):461-462, https://doi.org/10.1080/00028896809343035.

NIOSH [2007]. NIOSH pocket guide to chemical hazards. Cincinnati, OH: U.S. Department of Health and Human Services, Centers for Disease Control and Prevention, National Institute for Occupational Safety and Health, DHHS (NIOSH) Publication No. 2010-168c, http://www.cdc.gov/ niosh/npg/. 


\section{Lead}

ACGIH [2011]. Documentation of threshold limit values and biological exposure indices. Cincinnati, $\mathrm{OH}$ : American Conference of Governmental Industrial Hygienists. ISBN: 978-1-607260-28-8.

ACGIH [2019]. 2019 TLVs $^{\circledR}$ and BEIs ${ }^{\circledR}$ : threshold limit values for chemical substances and physical agents and biological exposure indices. Cincinnati, $\mathrm{OH}$ : American Conference of Governmental Industrial Hygienists.

ACOEM [2010]. ACOEM provides input to OSHA on key issues facing agency in 2010. Letter to David Michaels. Elk Grove Village, IL: American College of Occupational and Environmental Medicine, http:/ / beta.acoem.org/Page2Column.aspx?PageID=7392\&id=6676.

ACS [2011]. Lead. Atlanta, GA: American Cancer Society, http://www.cancer.org/cancer/cancercauses/othercarcinogens/athome/lead.

ATSDR [2007]. Toxicological profile for lead. Atlanta, GA: U.S. Department of Health and Human Services, Agency for Toxic Substances and Disease Registry, https://www.atsdr.cdc.gov/toxprofiles/tp.asp?id=96\&tid=22.

Billingsley KJ [2013]. Letter from KJ Billingsley, California Department of Public Health, to Juliann Sum, Division of Occupational Safety and Health (Cal/OSHA), California Department of Industrial Relations, September 30.

Brown-Williams H, Lichterman J, Kosnett M [2009]. Indecent exposure: lead puts workers and families at risk. Health Research for Action, University of California, Berkeley. Perspectives 4(1):1-9, http://www.healthresearchforaction.org/sites/default/files/PDF PERSPECTIVES IndecentExp $\% 20$ FNL 0.pdf.

CDC [2009]. Childhood lead poisoning associated with lead dust contamination of family vehicles and child safety seats_Maine, 2008. MMWR 58(32):890-893, https://www.cdc.gov/mmwr/preview/mmwrhtml/mm5832a2.htm.

CDC [2012]. Take-home lead exposure among children with relatives employed at a battery recycling facility-Puerto Rico, 2011. MMWR 61(47):967-970, https://www.cdc.gov/mmwr/preview/mmwrhtml/mm6147a4.htm?s cid=mm6147a4 w.

CDC [2013a]. Blood lead levels in children aged 1-5 years-United States, 1999-2010. MMWR 62(13):245-248, https://www.cdc.gov/mmwr/preview/mmwrhtml/mm6213a3.htm?s cid=mm6213a3 w.

CDC [2013b]. Very high blood lead levels among adults - United States, 2002-2011. MMWR 62(47):967-971, https://www.cdc.gov/ mmwr/preview/mmwrhtml/mm6247a6.htm.

CDC [2016]. National Notifiable Diseases Surveillance System (NNDSS), lead, elevated blood levels 2016 case definition, https://wwwn.cdc.gov/nndss/conditions/lead-elevated-blood-levels/casedefinition $/ 2016 /$.

CDC [2018]. Adult blood lead epidemiology and surveillance. Adult Blood Lead Epidemiology and Surveillance (ABLES), http://www.cdc.gov/niosh/topics/ables/description.html. 
CDPH [2009]. Medical guidelines for the lead-exposed worker. Sacramento, CA: California Department of Public Health, Occupational Lead Poisoning Prevention Program, https://www.cdph.ca.gov/Programs/CCDPHP/DEODC/OHB/OLPPP/CDPH $\% 20$ Document $\% 20$ Library/medgdln.pdf.

CDPH [2014]. Management guidelines for blood lead levels in adults. Sacramento, CA: California Department of Public Health, Occupational Lead Poisoning Prevention Program, https://www.cdph.ca.gov/Programs/CCDPHP/DEODC/OHB/OLPPP/CDPH $\% 20 D o c u m e n t \% 20$ Library/AdultMgtGuide.pdf.

CSTE [2009]. Public health reporting and national notification for elevated blood lead levels. CSTE position statement 09-OH-02. Atlanta, GA: Council of State and Territorial Epidemiologists, http://c.ymcdn.com/sites/www.cste.org/resource/resmgr/PS/09-OH-02.pdf.

CSTE [2013]. Management guidelines for blood lead levels in adults. Atlanta, GA: Council of State and Territorial Epidemiologists,

http://c.ymcdn.com/sites/www.cste.org/resource/resmgr/OccupationalHealth/ManagementGuidelin esforAdult.pdf.

CSTE [2015]. Public health reporting and national notification for elevated blood lead levels. CSTE position statement 15-EH-01. Atlanta, GA: Council of State and Territorial Epidemiologists, https://c.ymcdn.com/sites/www.cste.org/resource/resmgr/2015PS/2015PSFinal/15-EH-01.pdf.

DoD [2018]. Occupational and environmental health. Department of Defense Instruction. Department of Defense, DoD-6055.05-M. Washington, DC.

https://www.esd.whs.mil/Portals/54/Documents/DD/issuances/dodm/605505mp.pdf?ver=2017-0814-111314-123.

EPA [1998]. Risk analysis to support standards for lead in paint, dust, and soil. Environmental Protection Agency Publication EPA-747-R097-006. Washington, DC, https://www.epa.gov/lead/riskanalysis-support-standards-lead-paint-dust-and-soil-volume-i-chapters-1-7-and-appendix-epa.

Filon FL, Boeniger M, Maina G, Adami G, Spinelli P, Damian A [2006]. Skin absorption of inorganic lead (PbO) and the effect of skin cleansers. J Occup Environ Med 48(7):692-699, https://doi.org/10.1097/01.jom.0000214474.61563.1c.

HUD [2012]. Guidelines for the evaluation and control of lead-based paint hazards in housing, http://portal.hud.gov/hudportal/HUD?src=/program offices/healthy homes/lbp/hudguidelines.

IARC [2006]. Monographs on the evaluation of carcinogenic risks to humans. Vol. 87. Inorganic and organic lead compounds. Summary of data reported and evaluation. Lyon, France: World Health Organization, International Agency for Research on Cancer, https://monographs.iarc.fr/iarcmonographs-on-the-evaluation-of-carcinogenic-risks-to-humans-34/.

Institute of Medicine [2012]. Potential health risks from recurrent lead exposure of DOD firing range personnel. Washington, DC: National Academies Press, https://www.ncbi.nlm.nih.gov/books/NBK206966/pdf/Bookshelf NBK206966.pdf. 
Kosnett MJ, Wedeen RP, Rothenberg SJ, Hipkins KL, Materna BL, Schwartz BS, Hu H, Woolf A [2007]. Recommendations for medical management of adult blood lead exposure. Environ Health Perspect 115(3):463-471, https://doi.org/10.1289/ehp.9784.

Lauwerys RR, Hoet P [2001]. Industrial chemical exposure: guidelines for biological monitoring. 3rd ed. Boca Raton, FL: CRC Press, LLC, pp. 21-180.

Moline JM, Landrigan PJ [2005]. Lead. In: Rosenstock L, Cullen MR, Brodkin CA, Redlich CA, eds. Textbook of clinical occupational and environmental medicine. 2nd ed. Philadelphia, PA: Elsevier Saunders, pp. 967-979.

NIOSH [1995]. Report to Congress on the workers' home contamination study conducted under the Workers' Family Protection Act 29 U.S.C. 671a. Cincinnati, OH: U.S. Department of Health and Human Services, Centers for Disease Control and Prevention, National Institute for Occupational Safety and Health, DHHS (NIOSH) Publication No. 95-123, http://www.cdc.gov/niosh/docs/95123/.

NTP [2011]. Report on carcinogens: lead and lead compounds. 14th ed. Research Triangle Park, NC: U.S. Department of Health and Human Services, National Institutes of Health, National Institute of Environmental Health Sciences, National Toxicology Program, http://ntp.niehs.nih.gov/ntp/roc/twelfth/profiles/Lead.pdf.

NTP [2012]. NTP Monograph: health effects of low-level lead. Research Triangle Park, NC: U.S. Department of Health and Human Services, National Institutes of Health, National Institute of Environmental Health Sciences, National Toxicology Program, https://ntp.niehs.nih.gov/ntp/ohat/lead/final/monographhealtheffectslowlevellead newissn 508.pdf. OSHA [1978]. Lead 29 CFR 1910.1025. Washington, DC: U.S. Department of Labor, Occupational Safety and Health Administration, https://www.osha.gov/lawsregs/regulations/standardnumber/1910/1910.1025.

Schwartz BS, Hu H [2007]. Adult lead exposure: time for change. Environ Health Perspect 115(3):451454, https://doi.org/10.1289/ehp.9782.

Schwartz BS, Stewart WF [2007]. Lead and cognitive function in adults: a question and answers approach to a review of the evidence for cause, treatment, and prevention. Int Rev Psychiatry 19(6):671-692, https://dx.doi.org/10.1080/09540260701797936.

Stauber JL, Florence TM, Gulson B, Dale L [1994]. Percutaneous absorption of inorganic lead compounds. Sci Total Environ 145(1-2):55-70, https://dx.doi.org/10.1016/0048-9697(94)90297-6.

Sun CC, Wong TT, Hwang YH, Chao KY, Jee SH, Wang JD [2002]. Percutaneous absorption of inorganic lead compounds. Am Ind Hyg Assoc J 63(5):641-646, https://dx.doi.org/10.1080/15428110208984751.

\section{Other}

CFR. Code of Federal Regulations. Washington, DC: U.S. Government Printing Office, Office of the Federal Register, https://www.ecfr.gov/cgi-bin/ECFR?page=browse. 


\section{Delivering on the Nation's promise: Promoting productive workplaces through safety and health research}

Get More Information

Find NIOSH products and get answers to workplace safety and health questions:

1-800-C DC-INFO (1-800-232-4636) | TTY: 1-888-232-6348

CDC/NIOSH INFO: cdc.gov/info | cdc.gov/niosh

Monthly NIOSH eNews: cdc.gov/niosh/eNews 